\title{
Flupirtine protects both neuronal cells and lymphocytes against induced apoptosis in vitro: Implications for treatment of AIDS patients
}

\author{
Werner E.G. Müller ${ }^{1,4}$, Jürgen M. Dobmeyer², \\ Thomas S. Dobmeyer ${ }^{2}$, Gabriela Pergande ${ }^{3}$, Sanja Perovic ${ }^{1}$, \\ Jürgen Leuck ${ }^{1}$ and Rita Rossol ${ }^{1}$ \\ 1 Institut für Physiologische Chemie, Abteilung 'Angewandte \\ Molekularbiologie', Universität, Duesbergweg 6, 55099 Mainz, Germany \\ 2 Dritte Medizinische Klinik, Universität, Theodor Stern-Kai 7, 60590 Frankfurt, \\ Germany \\ ${ }^{3}$ ASTA Medica AG, Abteilung Medizin Deutschland, Weismüllerstraße 45, \\ 60314 Frankfurt, Germany \\ 4 corresponding author: W.E.G. Müller, Institut für Physiologische Chemie, \\ Abteilung Angewandte Molekularbiologie, Institut für Physiologische Chemie, \\ Universität Mainz; 55099 Mainz, Germany. tel: +6131 395910; fax: +6131 \\ 395243;
}

Received 16.4.96, revised 23.5.96, accepted 13.6.96 Edited by Y. Kuchino

\begin{abstract}
In the present study we demonstrate that flupirtine, an already clinically used, centrally acting, non-opiate analgesic agent, protects rat cortical neurons against HIV-gp120 induced apoptotic cell death. The drug was active at concentrations between 1 and $10 \mu \mathrm{g} / \mathrm{ml}$. Furthermore we show inhibition of in vitro induced apoptosis in human blood mononuclear cells, using flupirtine. Induced apoptosis in peripheral blood mononuclear cells from healthy individuals and HIV-1 infected patients was reduced to approximately $50 \%$ after in vitro preincubation with flupirtine at concentrations between 0.1 and $10 \mu \mathrm{g} / \mathrm{ml}$. The anti-apoptotic effect of flupirtine was restricted to $\mathrm{CD}^{+}$Iymphocytes and in particular to $\mathrm{CD} 4^{+}$cells. Flupirtine does not affect uninduced apoptosis in human lymphocytes in vitro. The selective potential of flupirtine to reduce apoptosis without influencing uninduced apoptosis may qualify this compound as a potential drug in the therapy of HIV-1 infected patients.
\end{abstract}

Keywords: flupirtine, apoptosis, apoptosis (uninduced), apoptosis (induced), HIV, AIDS, lymphocytes, neurons

Abbreviations: CDC, Centers for Disease Control; HIV-1, human immunodeficiency virus type $1 ; \mathrm{HX}$, hypoxanthine; LNAC, N-acetyl-L-cysteine; MNC, Mononuclear cells; NMDA, $\mathrm{N}$-methyl-D-aspartate; XOD, xanthine oxidase

\section{Introduction}

It remains a fundamental paradoxon of human immunodeficiency virus type 1 (HIV-1) caused disease that a progressive diminuation in $\mathrm{CD} 4^{+}$lymphocytes occurs despite the fact that only a small fraction of the cells is infected (Schattner and Laurence, 1994). In addition to lymphocytes, other cells such as human astrocytes (Rytik et al, 1991) and neuronal cells (Li et al, 1990) can be infected by HIV-1 in vitro. Primary neurons are very rarely, if at all infected by HIV-1 (Cheng-Meyer et al, 1987). The finding that exposure of rat cultured neurons to HIV-1 gp120 leads to apoptotic cell death was unexpected (Brenneman et al, 1988; Müller et al, 1992).

It has been argued that the mechanism for T-cell depletion in HIV-1 infection includes immune and autoimmune destruction of both infected and uninfected cells by apoptosis (Schattner and Laurence, 1994; Müller et al, 1989). In addition, HIV-1 causes apoptosis in neurons (Müller et al, 1992; Dreyer et al, 1990). Due to the fact that the clinically safe drug flupirtine-maleate [2-amino-3-ethoxycarbonylamino-6- (4-fluoro-benzylamino)pyridine maleate], a member of the class of triaminopyridines, displays an anti-apoptotic effect on neurons in vitro (Perovic et al, 1994), we have screened for its potential anti-apoptotic activity also in the lymphocyte system.

Flupirtine previously found to be a centrally acting, nonopiate analgesic agent (Szelenyi et al, 1989) is applied in the clinics under the trademark of Katadolon ${ }^{\circledR}$ (Friedel and Fitton, 1993). Recently we established flupirtine as an antiapoptotic drug for neurons in vitro (Perovic et al, 1994). It acts like an N-methyl-D-aspartate (NMDA) receptor antagonist but until now no binding at this receptor has been identified (Osborne et al, 1994; Schwarz et al, 1994; Osborne et al, 1996). Moreover, it was found that flupirtine enhances basal levels of ATP (Osborne et al, 1996) and reduces the NMDA-induced intracellular $\mathrm{Ca}^{2+}$ increase in vitro (Rupalla et al, 1995). In addition, flupirtine acts neuroprotectively at doses of $1-10 \mathrm{mg} / \mathrm{kg}$ in animal models of focal cerebral ischemia (mouse) (Rupalla et al, 1995) and global cerebral ischemia (rat) (Block et al, 1995) as well as of ischemia (rat, rabbit) (Block et al, 1994; Osborne et al, 1996).

Here we describe that flupirtine substantially abolishes the induced apoptotic cell death of lymphocytes both from AIDS patients and HIV-1 uninfected individuals. In addition it is shown that apoptosis, caused by HIV-1 gp120 in rat cortical cells, is completely blocked by flupirtine, while this drug displays no effect on cell death of permanent lymphocyte lines, infected by HIV-1. Important for future clinical trials is the finding, that flupirtine displays this effect only on induced and not on uninduced apoptosis. As an inducer for apoptosis in lymphocytes we used free oxygen radicals (Muschel et al, 1995), generated by the hypoxanthine/xanthine oxidase system (Bruck et al, 1994) as well as ionomycin (Gougeon et al, 1993) and for neurons the gp120 protein (Müller et al, 1992, 1996). 


\section{Results}

\section{Adjustment of the hypoxanthine/xanthine oxidase system}

The staining pattern for apoptosis, using 7-AAD, is shown in Figure 1 (right column). Apoptotic cells show a fluorescence intensity of $>10$ arbitrary channel numbers. At $0 \mathrm{mU} / \mathrm{ml}$ of XOD only $6.6 \pm 2.1 \%$ of the cells are above this borderline, indicating apoptosis. With increasing concentrations of XOD the percentage of apoptotic cells rose and reached at $80 \mathrm{mU} /$ $\mathrm{ml}$ a value of $93.2 \pm 6.8 \%$. Applying $10 \mathrm{mU} / \mathrm{ml}$ of $\mathrm{XOD}$ approximately $50 \%(54.6 \pm 6.1 \%)$ of the cells underwent apoptosis.

In Figure 1 (left column) it is shown that in the absence of XOD the cells showed a FSC/SSC distribution pattern as follows; size $349 \pm 27$ (arbitrary channel number) versus granularity $112 \pm 15$. At an enzyme concentration of $80 \mathrm{mU} /$ $\mathrm{ml}$ the size decreased to $256 \pm 22$ whereas the degree of granularity increased to $180 \pm 29$. These changes are also indicative for apoptotic morphological alterations of cells. At $10 \mathrm{mU} / \mathrm{ml}$ of XOD the cells show a distribution pattern which is approximately in the middle between these two extremes. If not mentioned otherwise, $10 \mathrm{mU} / \mathrm{ml}$ of $\mathrm{XOD}$ were used for the following experiments.

\section{Effect of flupirtine on rate of uninduced apoptosis in human MNC}

Peripheral blood MNC both from healthy individuals and from HIV-1 infected patients were analyzed for uninduced apoptosis one day after drawing blood. $6.32 \pm 0.82 \%$ of MNC from controls showed apoptosis, while $28.42 \pm 7.84 \%$ of those taken from HIV-1 individuals underwent this process (Figure 2). MNC from both groups were treated with flupirtine within a concentration range of 0.1 to $30 \mu \mathrm{g} / \mathrm{ml}$ for $24 \mathrm{~h}$. As summarized in Figure 2 the rate of uninduced apoptosis of MNC from uninfected and HIV-1 infected individuals did not change significantly.

\section{Reduction of apoptosis, induced by reactive oxygen, in human MNC by flupirtine}

MNC from healthy as well as HIV-1 infected individuals had been treated with $1 \mathrm{mM} \mathrm{HX}$ and $10 \mathrm{mU} / \mathrm{ml}$ XOD to induce apoptosis. Flupirtine was added at different concentrations to the cells $6 \mathrm{~h}$ prior to the inducer. As summarized in Figure 3, flupirtine at concentrations between 0.1 and $3 \mu \mathrm{g} / \mathrm{ml}$ significantly reduced the extent of apoptotic death $(p<0.001)$. At $10 \mu \mathrm{g} / \mathrm{ml}$ the protective effect was seen significantly $(p<0.001)$ only in the assays with MNC from infected individuals. At concentrations between 0.3 and $3 \mu \mathrm{g} /$ $\mathrm{ml}$ the protection of the cells against induced apoptosis was most pronounced; the reduction of induced apoptosis in the assays with MNC from healthy individuals was $\approx 40 \%$ and in those from HIV-1 infected patients $\approx 60 \%$.

Apoptosis in MNC from HIV-1 infected individuals was also traced by DNA fragmentation. After incubation of the cells with the HX/XOD system DNA was extracted from the cells, size-separated in an agarose gel and blot transferred. As shown in Figure $4 a$, the DNA degraded in a ladder-like pattern with fragments of multiples of $\approx 180$ base pairs. Such a pattern is characteristic for apoptotic DNA fragmentation (Wyllie, 1980). In cells treated with $1 \mu \mathrm{g} / \mathrm{ml}$ of flupirtine together with the inducer such a degradation pattern could not be seen (Figure 4b).

In control studies it was determined that flupirtine does not inhibit the enzyme activity of XOD at a concentration of $50 \mu \mathrm{g} / \mathrm{ml}$ (not shown); the assay was performed as described by Bergmeyer (1974).

\section{Reduction of ionomycin-induced apoptosis in mononuclear cells by flupirtine}

lonomycin $(1 \mu \mathrm{g} / \mathrm{ml})$ was used as a second inducer of apoptosis in MNC from healthy individuals. As shown in Figure 5, induced apoptosis was significantly $(p<0.001)$ reduced by flupirtine within the concentration range of 0.1 to $3 \mu \mathrm{g} / \mathrm{ml}$. The degree of induced apoptosis decreased from $44.3 \pm 6.2 \%$ (measured in the controls without flupirtine) to $22.4 \pm 5.6 \%$ if cells had been preincubated with $0.3 \mu \mathrm{g} / \mathrm{ml}$ of flupirtine.

\section{Effect of flupirtine on induced apoptosis in T-lymphocytes}

In order to investigate if the protective effect of flupirtine is restricted to a special T-lymphocyte population, a two colour flow cytometric assay was performed. Fragmented DNA was labeled with biotinylated dUTP using the enzyme TdT and visualized by FITC-avidin. The lymphocyte subpopulations were identified with specific antibodies. The results with antiCD3 antibodies are shown in Figure 6. In untreated cells (left blot) $>95 \%$ of the $\mathrm{CD}^{+}$as well as non-CD3 lymphocytes are non-apoptotic. If cells were treated with $\mathrm{HX} / \mathrm{XOD} 46.4 \pm 6.2 \%$ $(46.2 \pm 5.9 \%)$ of $\mathrm{CD}^{+}$(non-CD3) became apoptotic (blot in the middle). The degree of induced apoptosis decreased significantly $(\mathrm{p}<0.001)$ if those cells were treated with $1 \mu \mathrm{g} / \mathrm{ml}$ of flupirtine. Under these conditions only $18.9 \pm 2.1 \%$ $(32.3 \pm 4.9 \%)$ of the $\mathrm{CD}^{+}$(non-CD3) lymphocytes remained apoptotic (blot to the right).

Parallel experiments were performed with antibodies directed against $\mathrm{CD}^{+}$and $\mathrm{CD}^{+}$lymphocytes. These experiments demonstrated that flupirtine displayed also an anti-apoptotic effect against induced apoptosis in these lymphocyte subpopulations. It was determined that in the absence of flupirtine $22.9 \pm 4.9 \%$ of $\mathrm{CD}^{+}(28.3 \pm 5.2 \%$ $\mathrm{CD}^{+}$) underwent apoptotic cell death, if the cells were induced with $H X / X O D$. If $M N C$ had been pretreated with $1 \mu \mathrm{g} / \mathrm{ml}$ of flupirtine, the extent of apoptosis was reduced significantly $(p<0.001)$ to $11.8 \pm 1.8 \%(14.3 \pm 2.6 \%)$

\section{Neuroprotective effect of flupirtine on gp120 induced apoptosis in cortical cells}

For induction of apoptosis, rat cortical cells were treated with gp120. In the presence of $20 \mathrm{ng} / \mathrm{ml}$ of gp120 (incubation time of $18 \mathrm{~h}$ ) cell viability dropped from $75.9 \%$ (control) to $16.3 \%$ as checked by the MTT assay system (Table 1). DNA fragmentation (application of the sedimentation technique) increased from $13.1 \%$ (in the absence of gp120) to $92.2 \%$ (in 


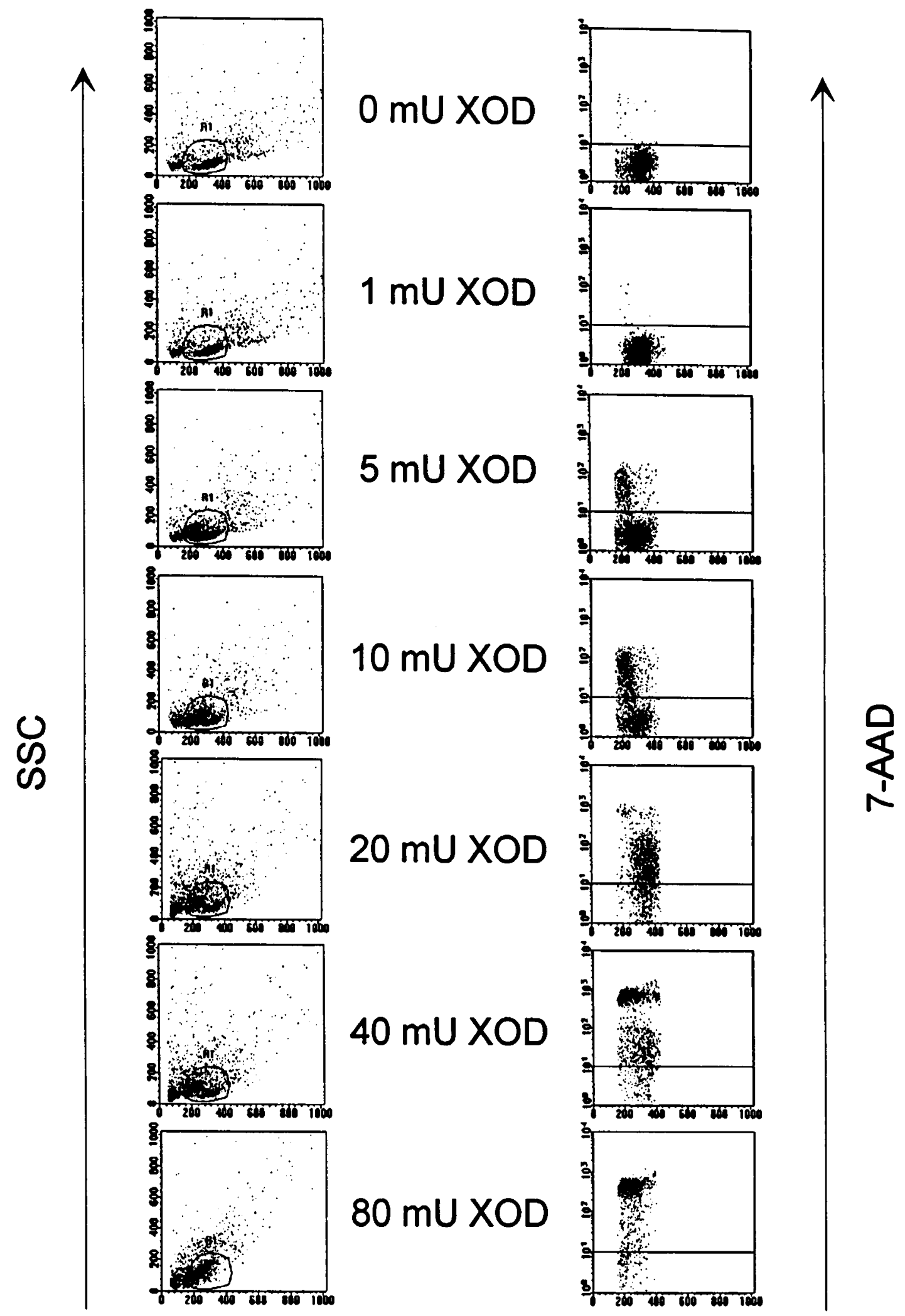

Figure 1 Induction of apoptosis by incubation of mononuclear cells (MNC) from healthy donors at a fixed concentration of hypoxanthine (HX; 1 mM) and increasing concentrations of xanthine oxidase (XOD; $\mathrm{mU} / \mathrm{ml})$. MNC were gated for analysis. Left column; the cells were analyzed by flow cytometry with respect to cell size (abscissa: FSC, forward light scatter) and cell granularity (ordinate: SSC, sideward/right angle light scatter). Right column; the cells were stained with 7$A A D$ and red fluorescence was analyzed by FACScan flow cytometer for cell size (abscissa) and fluorescence (ordinate). 


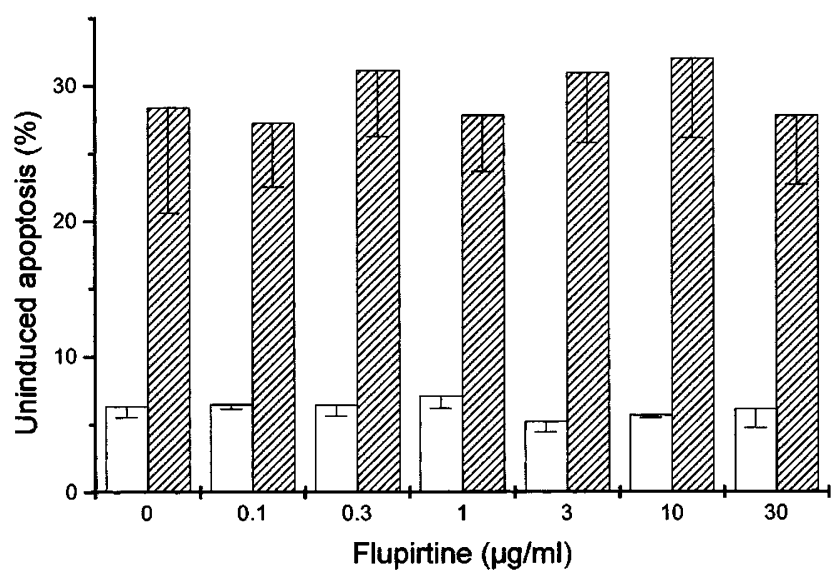

Figure 2 Effect of flupirtine on uninduced apoptosis of MNC from uninfected(open bars) and HIV-1 infected individuals (hatched bars); after 1 day the cells were analyzed by flow cytometry. MNC from 12 infected and eight uninfected individuals were studied; the mean values and the SD are indicated.

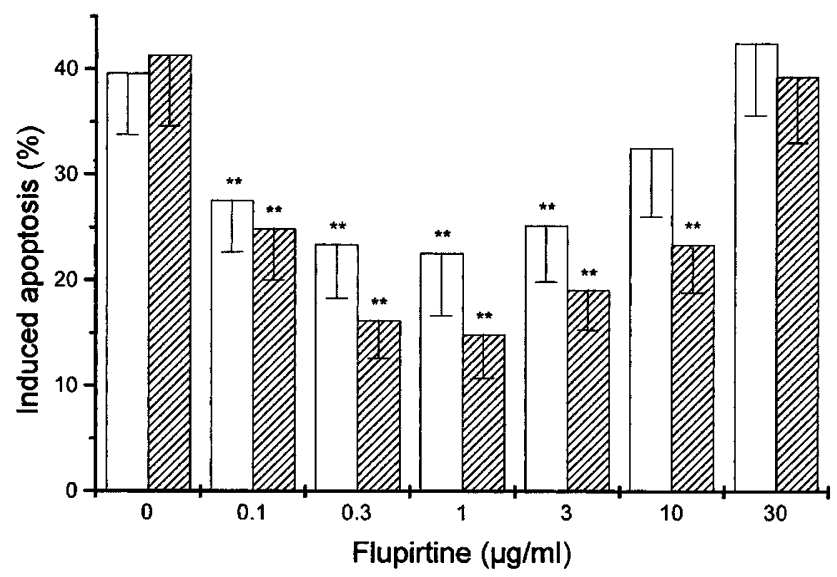

Figure 3 Reduction of induced apoptotic cell death of MNC by treatment with flupirtine. MNC from uninfected- (open bars) and HIV-1 infected individuals (hatched bars) were induced to apoptosis with HX/XOD. Flupirtine was added to the cells $6 \mathrm{~h}$ prior to the oxygen radical-generating system. One day later the cells were analyzed by flow cytometry. The values for uninduced apoptosis have been subtracted from the numbers measured. MNC from 12 infected and eight uninfected individuals were studied; the mean values and the SD are indicated. ${ }^{* *} \mathrm{p}<0.001$ (versus assay with $\mathrm{HX} / \mathrm{XOD}$ alone).

the presence of gp120) $(p<0.001)$. Incubation of cortical cells with different concentrations of flupirtine resulted in a dosedependent inhibition of the rate of the gp120-induced apoptosis (Table 1). DNA isolated from cultures incubated with $20 \mathrm{ng} / \mathrm{ml}$ of gp120 together with $1 \mu \mathrm{g} / \mathrm{ml}$ to $10 \mu \mathrm{g} / \mathrm{ml}$ of flupirtine showed a significant reduction in the percentage of DNA fragmentation $(p<0.001)$. Concomitantly with the decrease of DNA fragmentation the percentage of viable cells increased progressively $(p<0.001)$.

Under the conditions used a significant amount of cortical cells die - from $100 \%$ at the beginning of the incubation period to $75.9 \%$ - during the $18 \mathrm{~h}$ incubation period. This reduction can be significantly prevented by incubating the cells with flupirtine at concentrations higher than $3 \mu \mathrm{g} / \mathrm{ml} \quad(\mathrm{p}<0.001) \quad($ Table 1$)$. Simultaneously the

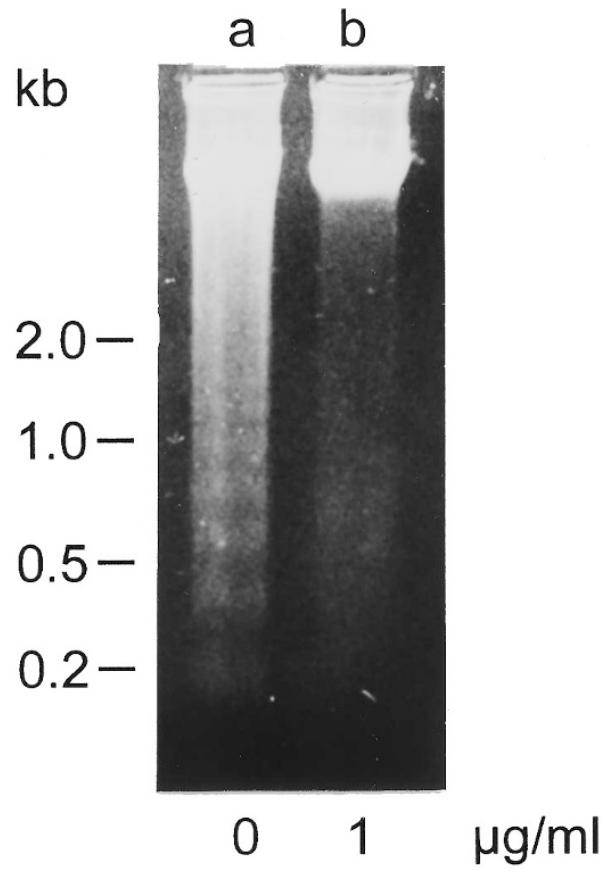

Figure $4 \mathrm{HX} / \mathrm{XOD}$-induced apoptotic fragmentation of DNA in MNC from HIV1 infected individuals. Cells were treated with the radical generating system and remained either without flupirtine (lane a) or were treated with $1 \mu \mathrm{g} / \mathrm{ml}$ of flupirtine (lane b) for 1 day. Then DNA was extracted from the cultures and analyzed by agarose $(1.2 \%)$ gel electrophoresis. The molecular masses are shown.

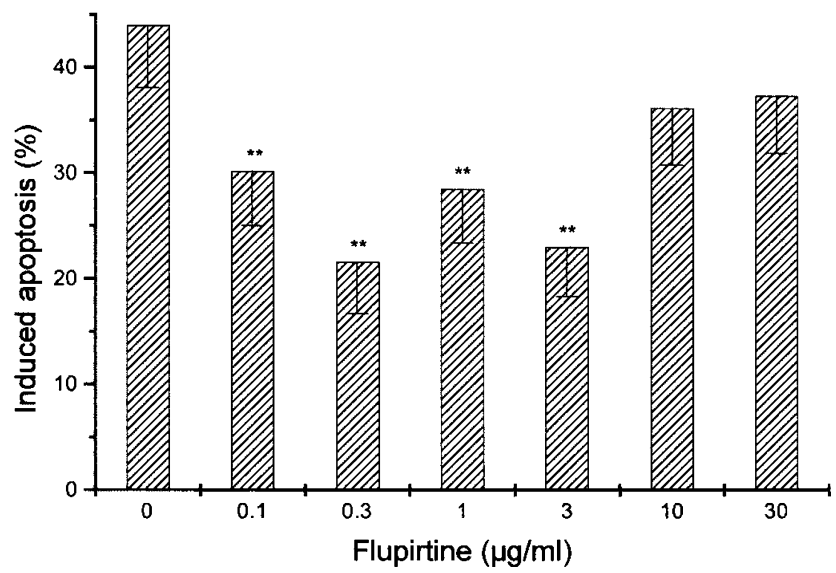

Figure 5 Effect of flupirtine on ionomycin-induced apoptotic cell death of MNC. MNC from uninfected individuals were induced to apoptosis with $1 \mu \mathrm{g} / \mathrm{ml}$ of ionomycin. Six hours prior to the addition of ionomycin flupirtine was added to the cells. One day later the cells were analyzed by flow cytometry. ${ }^{* *} \mathrm{p}<0.001$ (versus assay with ionomycin alone).

degree of DNA fragmentation is reduced (Table 1). This finding indicates that flupirtine acts neuroprotective also in the absence of the viral protein.

\section{Discussion}

Apoptosis is one major mechanism which balances homeostasis between cell proliferation and cell death in multi- 


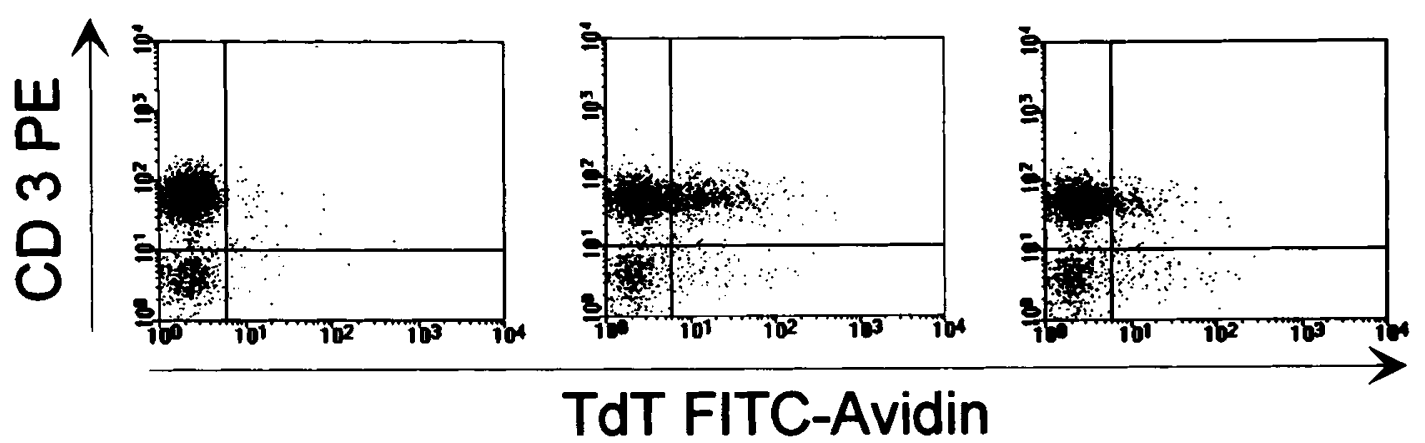

Figure 6 Effect of flupirtine on the degree of induced apoptosis in $\mathrm{CD}^{3+}$ lymphocytes. The cells were treated with biotinylated dUTP and TdT and subsequently incubated with FITC-avidin to identify fragmented DNA; in addition the cells were labelled with anti CD3 monoclonal antibodies conjugated to phycoerythrin (PE). Left dot blot: control cells; middle: cells treated with $1 \mathrm{mM} \mathrm{HX}$ and $10 \mathrm{mU} / \mathrm{ml} \mathrm{XOD;} \mathrm{right:} \mathrm{cells} \mathrm{treated} \mathrm{with} \mathrm{HX} / \mathrm{XOD}$ in the presence of $1 \mu \mathrm{g} / \mathrm{ml}$ of flupirtine. The upperleft quadrant contains $\mathrm{CD}^{3+}$, non-apoptotic cells; the lower-left shows the CD3-negative, non-apoptotic cells. The right quadrants show the corresponding apoptotic fractions.

Table 1 Effect of flupirtine on gp120-induced DNA fragmentation and cell viability. Rat cortical cell cultures were incubated in the absence or presence of $20 \mathrm{ng} / \mathrm{ml}$ of $\mathrm{gp} 120$

\begin{tabular}{lccc}
\hline $\begin{array}{l}\text { Addition of } \\
\mathbf{g p 1 2 0}(\mathbf{n g} / \mathbf{m l})\end{array}$ & $\begin{array}{c}\text { Flupirtine } \\
(\mu \mathbf{g} / \mathbf{m l})\end{array}$ & $\begin{array}{c}\text { DNA fragmen- } \\
\text { tation (\%) }\end{array}$ & $\begin{array}{c}\text { Viable cells } \\
(\%)\end{array}$ \\
\hline 0 & 0 & $13.1 \pm 3.3$ & $75.9 \pm 7.6$ \\
0 & 0.1 & $10.8 \pm 3.8$ & $77.0 \pm 7.3$ \\
0 & 1 & $8.4 \pm 2.4$ & $85.5 \pm 8.7$ \\
0 & 3 & $5.0 \pm 2.3^{*}$ & $94.3 \pm 5.2^{*}$ \\
0 & 10 & $6.5 \pm 2.2^{*}$ & $91.5 \pm 6.1^{*}$ \\
20 & 0 & $92.2 \pm 4.7$ & $16.3 \pm 2.6$ \\
20 & 0.1 & $82.4 \pm 7.5$ & $22.1 \pm 3.4$ \\
20 & 1 & $22.3 \pm 4.9^{\star *}$ & $31.3 \pm 5.6^{\star *}$ \\
20 & 3 & $18.2 \pm 4.0^{\star *}$ & $87.2 \pm 7.4^{\star *}$ \\
20 & 10 & $10.1 \pm 2.6^{\star *}$ & $83.8 \pm 7.7^{\star *}$ \\
\hline
\end{tabular}

Where indicated flupirtine was added to the cultures $2 \mathrm{~h}$ prior to the addition of gp120. The incubation time was $18 \mathrm{~h}$ as described under Materials and Methods. DNA fragmentation was determined by the sedimentation technique and total cell viability was assayed using the MTT test. Twelve parallel experiments were performed. ${ }^{*} p<0.001$ (Student's $t$-text versus assay without flupirtine); ${ }^{* *} p<0.001$ (versus assay with gp120 alone).

cellular organisms. The induction of apoptotic cell death can emanate from endogenous signals, or can be induced by extracellular signals (reviewed in: Vermes and Haanen, 1994; Thompson, 1995). Both (i) failure of cells to undergo apoptosis, e.g. in cancer patients, and (ii) excess of apoptotic cell death can be the basis of disorders, e.g. in AIDS. A variety of extrinsic signals have been described to induce apoptosis (reviewed in: Vermes and Haanen, 1994); in our group we identified (i) physiological activators, neurotransmitters (Müller et al, 1992), (ii) damage-related inducers, heat shock (Batel et al, 1993) and (iii) toxins, lead and prion protein (Perovic et al, 1995) as inducers of apoptosis. In AIDS patients excessive cell death has been described both for neurons and lymphocytes, a process which is assumed to be the major cause of this disease (Ameisen, 1992). In vitro, lymphocytes from HIV-1 infected individuals undergo uninduced apoptosis; a significant amount of lymphocytes taken from HIV-1 infected patients dies within $48 \mathrm{~h}$ in in vitro culture
(Gougeon, 1993). In addition, a series of extrinsic factors have been implicated in the initiation of 'induced' apoptosis in AIDS patients (Kabelitz et al, 1996).

It is very important not to interfere with the program causing uninduced apoptosis since this might result in proliferation disorders, e.g. cancer formation. One major task for a therapeutic intervention on cells undergoing apoptosis in AIDS patients is to block extracellularly induced apoptosis. Following this rationale, it was demonstrated that $\mathrm{N}$-acetyl-L-cysteine (LNAC) prevents trophic factor-induced apoptosis of neruonal cells (Ferrari et al, 1995) and also induced apoptosis in blood cells, e.g. lymphocytes (Sandstrom 1994) in vitro. Because LNAC acts also as an oxygen radical scavenger (Blanco et al, 1995) like the oncogen $b c /-2$ which is known to be (i) an antidote for apoptotic cell death (reviewed in: Tsujimoto, 1996) and (ii) downregulated in lymphocytes after HIV-1 infection (DeRossi et al, 1994), it was proposed to use this compound as a chemotherapeutic agent for AIDS patients. Unfortunately, data revealed that LNAC enhances HIV-1 replication (Nottet et al, 1994).

Flupirtine was effective against induced apoptosis in two cell systems: in lymphocytes and in neurons. Apoptosis in lymphocytes was induced by the oxygen radical forming HX/XOD system. The advantage of this inducer is the fact that it does not affect the expression of cytokines (to be published). Furthermore, the extent of apoptosis in a given cell system, here in lymphocytes, can be adjusted. Under the culture conditions used in the present study a ratio of $1 \mathrm{mM}$ of $\mathrm{HX}$ and $10 \mathrm{mM}$ of XOD caused apoptosis in approximately $50 \%$ of the lymphocytes. Using this system flupirtine significantly abolished the induced apoptosis at concentrations between 0.1 and $10 \mu \mathrm{g} / \mathrm{ml}$.

In another set of experiments MNC were treated with ionomycin to undergo apoptosis. This effect of ionomycin was described earlier (Gougeon et al, 1993). Flupirtine at 0.1 to $3 \mu \mathrm{g} / \mathrm{ml}$ acted also anti-apoptotic in this system. In parallel, we have performed experiments with HL-60 cells and induced them to apoptosis with $0.5 \mu \mathrm{g} / \mathrm{ml}$ actinomycin $D$ within an incubation period of $18 \mathrm{~h}$. In this system 
flupirtine displayed no protective effect within the concentration range of 0.1 to $10 \mu \mathrm{g} / \mathrm{ml}$ (to be published).

In a further series of experiments the anti-apoptotic effect displayed by flupirtine, was also demonstrated for Tlymphocyte subpopulations. The data showed that flupirtine protects $\mathrm{CD}^{+}$, as well as $\mathrm{CD}^{+}$and $\mathrm{CD}^{+}$lymphocytes, against apoptosis induced by the HX/XOD system.

Previously we reported that flupirtine displays an antiapoptotic effect on cortical cells from rat embryos induced to undergo apoptosis by intact HIV-1 particles (Perovic et al, 1994). Now we show, in a more defined system, that apoptosis of neuronal cells caused by purified HIV-1 gp120 is also prevented by flupirtine. The optimal concentration range which protected the cells was 1 to $10 \mu \mathrm{g} / \mathrm{ml}$. These doses are lower than those required in the earlier study using intact HIV-1 where at least $40 \mu \mathrm{g} / \mathrm{ml}$ had to be applied for $90 \%$ protection. From this finding we conclude that further molecules of the virus, other than pure protein gp120 are involved in the initiation of neuronal apoptosis.

Neuronal cells are known to undergo cell death in vitro, very likely due to the lack of neurotrophic agent(s) (reviewed in: Lo et al, 1995). It remains open, whether gp120 causes directly, or via a further cell type neuronal apoptosis (discussed in: Ushijima et al, 1995). It was found that neuronal apoptosis is almost completely blocked by flupirtine (Perovic et al, 1994). The anti-apoptotic mechanism displayed by flupirtine is not yet fully understood. As outlined in Introduction, flupirtine acts like an NMDA antagonist without binding to the NMDA receptor. Due to the fact that (i) the NMDA receptor is present exclusively at the postsynaptic membrane of excitatory synapses in the brain (Ehlers et al, 1995) and (ii) $1 \mathrm{mM}$ of glutamate does not significantly induce apoptosis in human lymphocytes (to be published), it appears likely that flupirtine displays its anti-apoptotic effect via a second mechanisms, e.g. increase of ATP level (Osborne et al, 1996).

Flupirtine is clinically safe; adverse reactions are minimal in incidence, nature and degree, with drowsiness as the most frequently reported reaction (approximately $10 \%$ of the patients (McMahon et al, 1987). Important for future therapeutical applications of the drug is the finding that after a single oral application of $200 \mathrm{mg}$ of flupirtine a peak concentration $\left(c_{\max }\right)$ of $2.4 \mu \mathrm{g} / \mathrm{ml}$ is reached in the plasma after $90 \mathrm{~min}$; the level of $\geqslant 1 \mu \mathrm{g} / \mathrm{ml}$ of flupirtine which was found to act anti-apoptotically in vitro remains there for $12 \mathrm{~h}$ (Hlavica and Niebch, 1985).

From these data we conclude that flupirtine is a potent anti-apoptotic compound in in vitro systems with lymphocytes which have been induced to undergo apoptosis by extracellular agents, such as the oxygen radical inducing system HX/XOD and ionomycin. In addition flupirtine acts anti-apoptotically on neurons against the deleterious effect caused by HIV-1 gp120. Furthermore, the neuroprotective effect of flupirtine has been proven in animal models of cerebral and retinal ischemia (Osborne et al, 1996; Rupalla et al, 1995; Block et al, 1995). Therefore, the results presented strongly suggest that flupirtine is a promising drug to treat not only (i) neurodegenerative disorders in general and AIDS-associated encephalopathia in particular but also (ii) induced apoptotic death of lymphocytes in AIDS patients.

\section{Materials and Methods}

\section{Materials}

Flupirtine maleate [2-amino-3-ethoxycarbonylamino-6-(4-fluoro-benzylamino)-pyridine maleate) ( $\left.\mathrm{M}_{\mathrm{r}}: 420,41\right)$ was obtained from ASTA Medica Corp. (Frankfurt/M, Germany).

Purified gp120 was prepared from HIV-infected H9 cells as described (Robey et al, 1986). The HIV-1 isolate IIIB was used (Popovic et al, 1984). The preparation was $>95 \%$ pure as checked by polyacrylamide gel electrophoresis (Müller et al, 1988).

\section{Blood samples}

Human peripheral blood samples were obtained from 12 HIV infected homosexual males (mean age 35 years, range 22-43 years) and from eight healthy HIV seronegative and 'risk-matched' males of about the same age (mean age 30 years, range 23-35 years). Patients were staged according to the Centers for Disease Control (CDC) surveillance definition (CDC, 1992). The study of HIV seropositive patients was performed with blood samples from asymptomatic carriers (CDC stages: $\mathrm{A} 1$ and $\mathrm{A} 2$, mean $\mathrm{CD} 4^{+}$cell count $407 / \mu \mathrm{l}$, range 209-698/ $\mu \mathrm{l})$. None of the patients had malignancies, symptomatic infections or any immunosuppressive treatment i.e. corticosteroids 10 weeks before sampling (Voth et al, 1988).

\section{Cell preparation and treatment}

Mononuclear cells (MNC) were isolated from heparinized blood by centrifugation on a Ficoll Hypaque density gradient (Voth et al, 1988). $0.5 \times 10^{6}$ cells were cultured in $500 \mu$ medium composed of MEM supplemented with $10 \mathrm{mM}$ HEPES buffer, $2.6 \%$ sodium bicarbonate, $0.1 \mathrm{U} / \mathrm{ml}$ penicillin, $0.1 \mathrm{U} / \mathrm{ml}$ streptomycin, $10 \%$ FCS and $1 \mathrm{mM}$ glutamine. Where indicated, the cells were treated immediately after isolation with flupirtine.

\section{Induction of apoptosis in MNC by reactive oxygen species and ionomycin}

Reactive oxygen species were generated using hypoxanthine $(\mathrm{HX})$ and xanthine oxidase (XOD) (Bruck et al, 1994). To induce apoptosis MNC were cultured for $24 \mathrm{~h}$ in a total volume of $500 \mu \mathrm{l}$ MEM medium containing 0 to $80 \mathrm{mU} / \mathrm{ml}$ of XOD and $1 \mathrm{mM}$ of HX. At $80 \mathrm{mU} / \mathrm{ml}$ of XOD (Sigma) $>90 \%$ of MNC underwent apoptosis. If not mentioned otherwise, $10 \mathrm{mU} / \mathrm{ml}$ of XOD and $1 \mathrm{mM} \mathrm{HX}$ have been used for the studies. Under these experimental conditions approximately $50 \%$ of the MNC underwent apoptosis. This degree is desirable for studies in which a given compound is tested for potential inhibition and/or stimulation of apoptotic cell death. As a second inducer of apoptosis we applied ionomycin at a concentration of $1 \mu \mathrm{g} / \mathrm{ml}$.

Flupirtine was applied to the cells $6 \mathrm{~h}$ prior to the addition of the oxygen radical producing system or ionomycin and incubation was terminated after 1 day.

\section{Analysis of cells by flow cytometry}

Apoptosis was measured in a flow cytometer FACScan (Becton Dickinson) with an argon laser turned to $488 \mathrm{~nm}$, according to the 
technique described by Schmid et al (1994). MNC were gated for analysis by a combination of forward light scatter (a measure for the size of cells, FSC) and right angle light scatter (granularity; SSC) properties. To stain apoptotic cells MNC were incubated with $20 \mu \mathrm{g} / \mathrm{ml}$ of 7-aminoactinomycin D (7-ADD) (Sigma) in PBS for $20 \mathrm{~min}$ at $4^{\circ} \mathrm{C}$ under light protection. Then the cells could be analyzed by the flow cytometer in the staining solution. The red fluorescence of 7-AAD was filtered through a $650 \mathrm{~nm}$ long pass filter. 7-AAD penetrates into apoptotic cells due to loss of membrane integrity and stains DNA by intercalation. The data analysis was performed using LYSYS II software. Mean channel numbers were converted to mean intensity of fluorescence, cell size and granularity.

\section{Fluorescence in situ TdT assay and cell surface staining}

In order to define the cell subsets undergoing apoptosis the terminal desoxynucleotidyltransferase (TdT) assay was applied, as described by Gorczyca et al (1993) with minor modifications. Cells in suspension were washed twice in PBS and fixed in 1\% paraformaldehyde (Riedel de Haen) for $10 \mathrm{~min}$ at $4^{\circ} \mathrm{C}$. Then cells were washed twice in PBS (supplemented with $5 \% \mathrm{AB}$ serum and $0.5 \%$ bovine serum albumin (BSA)), pelleted and resuspended in $50 \mu \mathrm{l}$ of $2.5 \mathrm{mM}$ cobalt chloride solution, containing $0.5 \mathrm{nM}$ of biotin-16-dUTP and $25 \mathrm{U}$ of TdT in a reaction buffer containing $200 \mathrm{mM}$ potassium cacodylat, $25 \mathrm{mM}$ Tris$\mathrm{HCl}$ and $0.25 \mathrm{mg} / \mathrm{ml} \mathrm{BSA}$; incubation was proceeded at $37^{\circ} \mathrm{C}$ for $30 \mathrm{~min}$. Cells were washed twice in PBS $(5 \% \mathrm{AB}$ serum and $0.5 \%$ BSA) and resuspended in $100 \mu \mathrm{l}$ of staining buffer, which contained $5 \mu \mathrm{g} / \mathrm{ml}$ of fluorescein isothiocyanate (FITC)-labeled avidin (cell sorter grade) (Serva). For simultaneous cell surface staining $20 \mu \mathrm{g} / \mathrm{ml}$ of phycoerythrin-labeled monoclonal anti-CD3-, anti-CD4- or anti-CD8antibodies (Becton Dickinson) were added. Fluorescence was assessed on a flow cytometer (Halliwell, 1987).

\section{Rat cortical cells}

Primary cortical cells were prepared from the brains of 18 days old Wistar rat embryos by dissociation as described previously (Perovic et al, 1994, 1995). Briefly, cells were dissociated with $0.025 \%$ of trypsin, placed into polylysine-coated plastic flasks and cultivated in growth medium (Dulbecco's modified Eagle's medium (DMEM), supplemented with $30 \mathrm{mM}$ glucose, $100 \mathrm{mU} / \mathrm{l}$ of insulin, $2 \mathrm{mM}$ glutamate, $0.1 \mathrm{U} /$ $\mathrm{ml}$ penicillin, $0.1 \mathrm{U} / \mathrm{ml}$ streptomycin) with $10 \%$ FCS. To enrich the percentage of neurons the cultures were incubated for $24 \mathrm{~h}$ in the presence of $10 \mu \mathrm{M}$ of cytosine arabinoside. The cultures contained $>90 \%$ of neurons; the other cells were astrocytes (Boehringer detection kit) and macrophages (Perovic et al, 1994). One day later the cells were used for the experiments.

\section{Treatment of cortical cells with gp120}

Cells were treated with $20 \mathrm{ng} / \mathrm{ml}$ of gp120 in phosphate-buffered saline $\left(\mathrm{Ca}^{2+}\right.$ - and $\mathrm{Mg}^{2+}$-free; containing $25 \mathrm{mM}$ Tris/ $\mathrm{HCl}(\mathrm{pH} 7.4)$ and $15 \mathrm{mM}$ glucose). Flupirtine was added to cells $2 \mathrm{~h}$ prior to the viral protein; the total incubation period was $18 \mathrm{~h}$.

DNA fragmentation was determined as follows: firstly, fragmentation was determined qualitatively by electrophoresis on horizontal agarose gels. The modified highly sensitive method (labelling of extracted DNA with biotin-dUTP-size separation on agarose gelsblot-transfer-visualization by streptavidin alkaline phosphatase-BCIP/ NBT) was applied (Lauc et al, 1994). Secondly, for quantitative analysis of DNA fragmentation the sedimentation technique was applied (Wyllie, 1980).
The viability of total cells was determined with the MTT colorimetric assay system (Scudiero et al, 1988), followed by evaluation with an ELISA plate reader (BioRad 3550, equipped with the program NCIMR IIIB).

\section{Statistical analysis}

The results were analyzed by paired Student's t-test (Sachs, 1984).

\section{Acknowledgements}

The authors would like to thank Drs. L. Montagnier, M.L. Gougeon and R. Zinkernagel for helpful comments and suggestions. This work was supported by grants from the Bundesminsterium für Bildung und Forschung (Verbundprojekt 'Infektionsforschung') and from the Deutsche Forschungsgemeinschaft (fellowships TSD Do 559/1-1; JMD Do 537/1-1).

\section{References}

Ameisen JC (1992) Programmed cell death and AIDS: from hypothesis to experiment. Immunol. Today 13: 388-391

Batel R, Bihari N, Rinkevich B, Dapper J, Schäcke H, Schröder HC and Müller WEG (1993) Modulation of organotin-induced apoptosis by the water pollutant methyl mercury in a human lymphoblastoid tumor cell line and a marine sponge. Marine Ecol. 93: 245-251

Bergmeyer HU (1974) Methoden der enzymatischen Analyse. Verlag ChemieWeinheim; pp. 682-688

Blanco FJ, Ochs RL, Schwarz H and Lotz M (1995) Chondrocyte apoptosis induced by nitric oxide. Am. J. Pathol. 146: 75-85

Block F, Pergande G and Schwarz M (1994) Flupirtine protects against ischaemic retinal dysfunction in rats. NeuroReport 5: 2630-2632

Block F, Pergande G and Schwarz M (1995) Flupirtine reduces functional and morphological consequences induced by global ischemia in rats. Europ. J. Neurosc. Suppl. 8: 24

Brenneman DE, Westbrook GL, Fitzgerald SP, Ennist DL, Elkins KL, Ruff MR and Pert CB (1988) Neuronal cell killing by the envelope protein of HIV and its prevention by vasoactive intestine peptide. Nature 335: 639-642

Bruck W, Bruck Y, Diederich U and Friede RL (1994) Dorsal root ganglia cocultured with macrophages: an in vitro model to study experimental demyelination. Acta Neuropathol. Berl. 88: 459-464

CDC1993 (1992) revised classification system for HIV infection and expanded surveillance case definition for AIDS among adolescents and adults. M.M.W.R 41: $1-29$

Cheng-Mayer C, Rutka JT, Rosenblum ML, McHugh T, Stites DP and Levy JA (1987) Human immunodeficiency virus can productively infect cultured human glial cells. Proc. Natl. Acad. Sci. USA 84: 3526-3529

De Rossi A, Ometto L, Roncella S, d'Andrea E, Menin C, Calderazzo F, Rowe M, Ferrarini M and Chieco-Bianchi L (1994) HIV-1 induces down-regulation of bcl-2 expression and death by apoptosis of EBV-immortalized B cells: a model for persistent 'self-limiting' HIV-1 infection. Virology 198: 234-244

Dreyer EB, Kaiser PK, Offermann JT and Lipton SA (1990) HIV-1 coat protein neurotoxicity prevented by calcium channel antagonists. Science 248: $364-$ 367

Ehlers MD, Tingley WG and Huganir RL (1995) Regulated subcellular distribution of the NR1 subunit of the NMDA receptor. Science 269: 1734-1737

Ferrari G, Yan CY and Greene LA (1995) N-acetylcysteine (D- and L-stereoisomers) prevents apoptotic death of neuronal cells. J. Neurosci. 15: 2857-2866

Friedel HA and Fitton A (1993) Flupirtine. A review of its pharmacological properties and therapeutic efficacy in pain patients. Drug 45: $548-569$

Gorczyca W, Gong J and Darzynkiewicz Z (1993) Detection of DNA strand breaks in individual apoptotic cells by the in situ terminal deoxynucleotidyl transferase and nick translation assays. Cancer Research 53: 1945-1951

Gougeon ML, Garcia S, Heeney J, Tschopop R, Lecoeur H, Guetard D, Rame V, Dauguet $C$ and Montagnier L (1993) Programmed cell death in AIDS-related HIV and SIV infection. AIDS Res. Human Retrovir. 9:553-563 
Halliwell B (1987) Oxidants and human disease: some new concepts. FASEB J. 1: $358-364$

Hlavica P and Niebch G (1985) Untersuchungen zur Pharmakokinetik und Biotransformation des Analgetikums Flupirtin beim Menschen. Drug Res. 35: $42-49$

Kabelitz D, Pohl T, Oberg HH, Pechhold K, Dobmeyer T and Rossol-Voth R (1996) Apoptosis of mature $T$ lymphocytes: putative role in the regulation of cellular immune responses and in pathogenesis of HIV infection. In: Kuchino Y, Müller WEG (eds.) Apoptosis. Springer-Verlag-Berlin; pp. 58-71

Lauc G, Perovic S, Dapper J, Flögel M, Iskric S and Müller WEG (1994) A nonradioactive sensitive method for the detection of DNA fragmentation in apoptotic cells (rat phenochromocytoma PC12 cells and rat cortical cells). Analytical Cell Pathol. 7: 107-114

Li XL, Moudgil T, Vinters HV and Ho DD (1990) CD4-independent, productive infection of a neuronal cell line by human immunodeficiency virus type 1. J. Virol. 64: $1383-1387$

Lo AC, Houenou LJ and Oppenheim RW (1995) Apoptosis in the nervous system: morphological features, methods, pathology, and prevention. Arch. Histol. Cytol. 58: $139-149$

McMahon FG, Arndt WF, Newton JJ, Montgomery PA and Perhach JL (1987) Clinical experience with Flupirtine in the US. Postgrad. Med. J. 63: 81-85

Müller WEG, Renneisen K, Kreuter MH, Schröder HC and Winkler I (1988) The Dmannose-specific lectin from Gerardia savaglia blocks binding of human immunodeficiency virus type I to $\mathrm{H} 9$ cells and human lymphocytes in vitro. J. Acquir. Immune Def. Syndr. 1: 453-458

Müller WEG, Reuter P, Kichino Y, v Rooyen J and Schröder HC (1989) Inhibitory effect of nonviable preparations from human immunodeficiency virus 1 on inositol phospholipid metabolism. Eur. J. Biochem. 183: 391-396

Müller WEG, Schröder HC, Ushijima H, Dapper J and Bormann J (1992) Gp120 of HIV-1 induces apoptosis in rat cortical cell cultures: prevention by memantine. Eur. J. Pharmacol. (Mol. Pharmacol. Sec.) 226: 209-214

MüllerWEG, Pergande G, Schleger C, Ushijima Hand Perovic S (1996) Neurotoxicity in rat cortical cells caused by N-methyl-D-aspartate (NMDA) and gpl120 of HIV-1: induction and pharmacological intervention. In: Kuchino Y, Müller WEG. (eds.) Apoptosis. Springer-Verlag-Berlin; pp. 44-57

Muschel RJ, Bernhard EJ, Garza L, McKenna WG and Koch CJ (1995) Induction of apoptosis at different oxygen tensions: evidence that oxygen radicals do not mediate apoptotic signaling. Cancer Res. 55: 995-998

Nottet HS, van Asbeck BS, de Graaf L, de Vos NM, Visser MR and Verhoef J (1994) Role of oxygen radicals in self-sustained HIV-1 replication in monocyte-derived macrophages: enhanced HIV-1 replication by N-acetyl-L-cysteine. J. Leukoc. Biol. 56: 702-707

Osborne NN, Pergande G, Block F and Schwarz M (1994) Immunohistochemical evidence for flupirtine acting as an antagonist on the $\mathrm{N}$-methyl-D-aspartate and homocysteic acid-induced release of GABA in the rat retina. Brain Res. 667: $291-294$

Osborne NN, Schwarz M, Pergande G (1996) Protection of rabbit retina from ischemia injury by flupirtine. Invest. Ophthal Vis Sci. 37: 274-280

Perovic S, Schleger C, Pergande G, Iskric S, Ushijima H, Rytik P and Müller WEG (1994) The triaminopyridine flupirtine prevents cell death in rat cortical cells induced by N-methyl-D-aspartate and gp120 of HIV-1. Eur. J. Pharmacol. 288: $27-33$

Perovic S, Pergande G, Ushijima H, Kelve M, Forrest J and Müller WEG (1995) Flupirtine partially prevents neuronal injury induced by Prion protein fragment and lead acetate. Neurodegeneration 4: $369-374$

Popvic M, Sarngadharan MG, Read E and Gallo RC (1984) Detection, isolation and continuous production of cytopathic retrovirues (HTLV-III) from patients with AIDS and Pre-AIDS. Nature 224: 497-500

Robey WG, Arthur LO, Matthews TJ, Langlois A, Copeland TD, Lerche NW, Orozlan S, Bolognesi DP, Gilden RV and Fischinger PJ (1986) Prospect for prevention of human immunodeficiency virus infection. Purified 120-kDa envelope glycoproetin induces neutralizing antibody. Proc. Natl. Acad. Sci. USA 83: 70237027

Rupalla K, Cao W and Krieglstein J (1995) Flupirtine protects neurons against excitotoxic or ischemic damage and inhibits the increase in cytosolic $\mathrm{Ca} 2+$ concentrations. Europ. J. Pharmacol. 294: 469-473

Rytik PG, Eremin V, Kvacheva ZB, Poleschuk NN, Popov SA, Schröder HC, Bachmann M, WeilerBE and Müller WEG (1991) Susceptibility of primary human glial fibrillary acidic protein-positive brain cells to human immunodeficiency virus infection in vitro: anti-HIV activity of Memantine. J. Acquir. Immune Def. Syndr. 7: $89-95$

Sachs L (1984) Angewandte Statistik. Springer-Verlag-Berlin; p. 242

Sandtrom PA, Mannie MD and Buttke TM (1994) Inhibition of activation-induced death in T cell hybridomas by thiol antioxidants: oxidative stress as a mediator of apoptosis. J. Leukoc. Biol. 55: 221-226

Schattner E and Laurence J (1994) HIV-induced T-lymphocyte depletion. Clin. Lab. Med. 14: 221-238

Schmid I, Uittenbogaart CH, Keld B and Giorgi JV (1994) A rapid method for measuring apoptosis and dual-color immunofluorescence by single laser flow cytometry. J. Immunol. Methods. 170: 145-157

Schwarz M, Block F and Pergande G (1994) N-methyl-D-aspartate (NMDA)mediated muscle relaxant action of flupirtine in rats. NeuroReport 5: 1981 - 1984

Scudiero DA, Shoemaker RH, Paull KD, Monks A, Tierney S, Nofziger TH, Currens MJ, Seniff D and Boyd MR (1988) Evaluation of a soluble tetrazolium/formazan assay for cell growth and drug sensitivity in culture using human and other tumor cell lines. Cancer Res. 48: 4827-4833

Szelenyi I, Nickel B, Borbe HO and Brune K (1989) Mode of antinociceptive action of Flupirtine in the rat. Br. J. Pharmacol. 97: 835-842

Thompson CB (1995) Apoptosis in the pathogenesis and treatment of disease. Science 267: $1456-1462$

Tsujimoto Y (1996) bcl-2: antidote for cell death. In: Kuchino Y, Müller WEG (eds.) Apoptosis. Springer-Verlag-Berlin; pp. 72-86

Ushijima H, Nishio O, Klöcking R, Perovic S and Müller WEG (1995) Exposure to gp120 of HIV-1 induces an increased release of arachidonic acid in rat primary neuronal cell culture followed by NMDA receptor mediated neurotoxicity. Europ. J. Neurosci. 7: 1353-1359

Vermes I and Haanen C (1994) Apoptosis and programmed cell death in health and disease. Ad. Clin. Chem. 31: 177-246

Voth R, Rossol D, Gräff E, Laubenstein Hp, Schröder HC, Müller WEG, Meyer zum Büschenfelde KH and Hess G (1988) Natural killer cell activity as a prognostic parameter in the progression to AIDS. J. Infec. Dis. 157: 851-852

Wyllie AH (1980) Glucocorticoid-induced thymocyte apoptosis is associated with endogenous nuclease activation. Nature 284: 555-556 